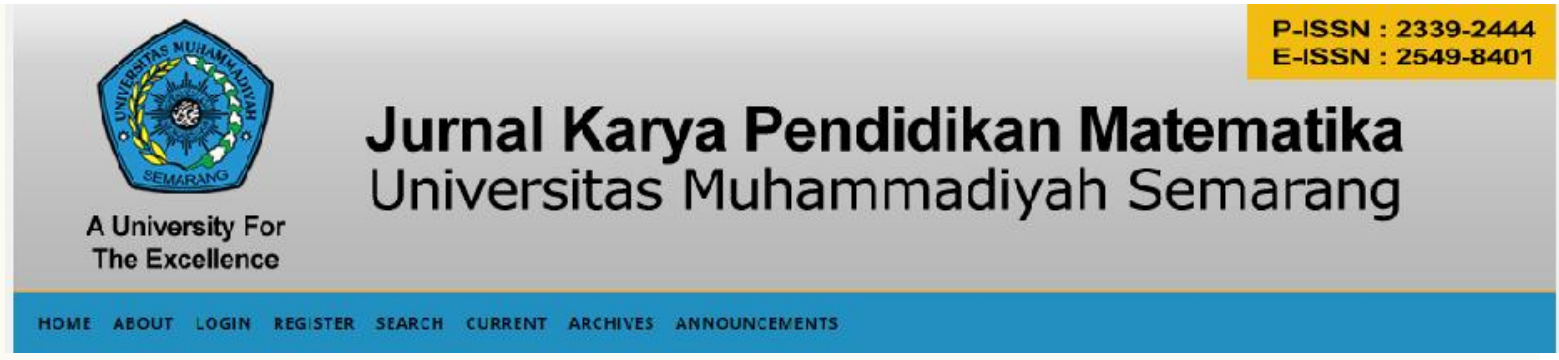

\title{
PROFIL BERPIKIR KRITIS DALAM PEMECAHAN MASALAH SOAL CERITA MATEMATIKA DITINJAU DARI GAYA KOGNITIF SISWA
}

\author{
Oleh: Yohana Eka Kusuma Dewi ${ }^{1}$, Sutriyono ${ }^{2}$, Fika Widya Pratama ${ }^{3}$ \\ Universitas Kristen Satya Wacana \\ 202015030@student.uksw.edu ${ }^{1}$, sutriyono@staff.uksw.edu ${ }^{2}$, fika.pratama@uksw.edu ${ }^{3}$
}

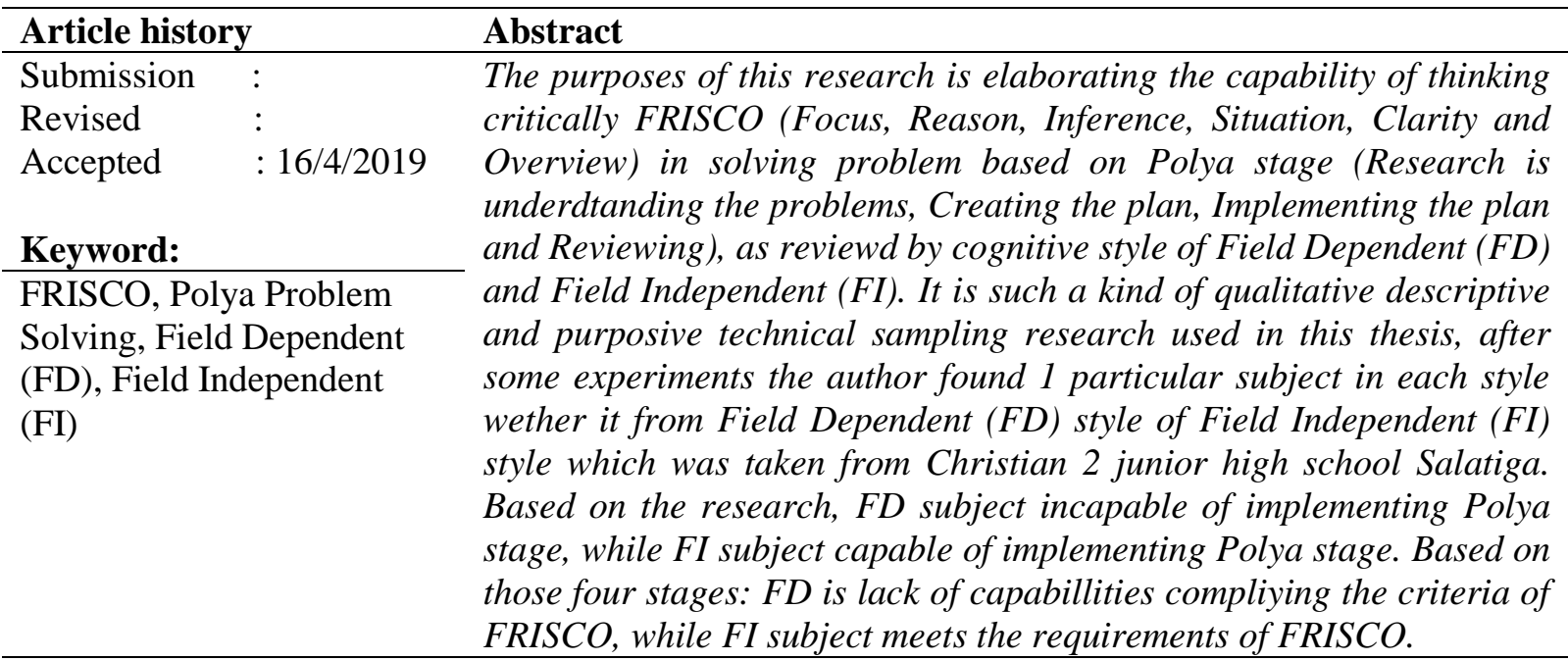

\section{Pendahuluan}

Manusia memerlukan solusi yang tepat untuk menyelesaikan masalah yang dihadapinya, agar mendapatkan solusi tersebut maka manusia berpikir. Menurut (Santrock, 2004:357) berpikir adalah memanipulasi atau mengelola dan mentranformasi informasi dalam memori. Kegiatan manusia ketika mengelola informasi di dalamnya terdapat usaha untuk menentukan dan memutuskan informasi yang akan digunakan sebagai solusi permasalahannya.

Usaha yang dilakukan manusia dalam mengelola informasi memerlukan berpikir kritis, karena dengan berpikir kritis manusia dapat membuat keputusan, sehingga menghasilkan solusi yang berguna untuk menyelesaikan masalah. Ennis (Fisher, 2008:4) mengemukakan berpikir kritis adalah pemikiran yang masuk akal dan reflektif yang berfokus untuk memutuskan apa yang mesti dipercaya dan dilakukan. Kriteria atau elemen 
berpikir kritis menurut Ennis (Cahyono, 2017:52) disingkat menjadi FRISCO, yang meliputi Focus yaitu perhatian siswa dalam memahami masalah yang terdapat di dalam soal, Reason adalah alasan siswa pada setiap langkah penyelesainnya berdasarkan fakta yang ada, Inference merupakan kesimpulan siswa disertai alasan yang masuk akal, Situation yaitu perhatian siswa dengan seksama dalam menggunakan informasi untuk menyelesaikan permasalahan yang ada, Clarity merupakan penjelasan oleh siswa, dapat berupa penjelasan istilah yang digunakan dan Overview adalah pengecekan kembali oleh siswa dari awal sampai akhir yang sudah dihasilkan pada FRISC. Kriteria berpikir kritis tersebut saling berkaitan dan bukan serangkaian langkah-langkah (Mahardingirum, 2018:77).

Berpikir kritis juga diperlukan dalam pembelajaran matematika, peraturan Menteri Pendidikan Nasional No. 22 Tahun 2006 menyatakan bahwa mata pelajaran matematika perlu diberikan kepada semua peserta didik dengan kemampuan logis, analitis, sistematis, kritis, dan kreatif, serta kemampuan bekerjasama. Penerapan berpikir kritis dalam pembelajaran matematika dapat diterapkan ke dalam bentuk pemecahan masalah. Ini diperkuat oleh (Cahyono, 2017:51) yang menyatakan bahwa profil berpikir kritis yang dimiliki siswa dapat dilihat dari aktivitas siswa dalam menyelesaikan masalah.

Kenyataannya siswa masih merasa kesulitan dalam memecahkan masalah pada bentuk soal cerita. Utomo (Ifnali, 2014:147) menyatakan bahwa soal matematika dalam bentuk soal cerita sulit diselesaikan, hal ini terjadi karena kurangnya kemampuan siswa dalam mengubah kalimat verbal ke dalam model matematika serta kurangnya kemampuan dalam menginterpretasikan penyelesaian matematika menjadi masalah nyata. Pernyataan tersebut menjadi bukti bahwa pemecahan masalah pada pembelajaran matematika sangat penting, terutama dalam bentuk soal cerita. Hal ini didukung oleh (Ifnali, 2014:147) yang menyatakan melalui pemberian soal matematika yang berbentuk cerita memberikan pengalaman bagi siswa untuk dapat memecahkan masalah matematika.
Pemecahan masalah model Polya (Ifnali, 2014:148) digunakan dalam penellitia ini, agar dengan model tersebut siswa dapat terampil dalam memecahkan masalah. Pemecahan masalah tahapan Polya terdiri dari empat tahap, yaitu 1) Memahami masalah, tahap ini mengharuskan siswa memahami masalah yang terdapat di dalam soal, sehingga siswa mengerti data yang terdapat di dalam soal maupun data yang perlu di cari, sehingga membantu siswa mengetahui cara penyelesaian yang benar dan tepat. 2) Membuat rencana penyelesaian, pada tahap ini siswa diwajibkan untuk melhat hubungan antara data yang diketahui dengan data yang perlu dicari, sehingga mampu memikirkan langkah-langkah penyelesainnya, siswa juga di haruskan dapat menentukan konsep maupun rumus yang digunakan. 3) Melaksanakan rencana, siswa diharuskan dapat melaksanakan strategi atau rumus maupun konsep yang sudah di pilih sebelumnya, sehingga menghasilkan jawaban yang benar dan tepat. 4) Mengecek/ memeriksa kembali, siswa diharapkan dapat mengecek kembali jawaban yang sudah dibuatnya, tahap ini mengajari siswa untuk teliti dalam menyelesaikan soal.

Materi yang dikemas peneliti untuk melihat profil berpikir kritis dalam memecahkan masalah matematika yaitu materi Sistem Persamaan Linear Dua Variabel (SPLDV), karena soal cerita pada materi tersebut dapat melatih siswa menguasai konsep dalam memecahkan masalah. Ini diperkuat oleh (Bahri, 2009:79) yang menyatakan bahwa salah satu konsep matematika yang memerlukan penguasaan dalam pemecahan masalah adalah materi SPLDV.

Berpikir kritis yang dimiliki siswa dalam menyelesaikan masalah dipengaruhi oleh gaya kognitif yang dimilikinya. (Nisa, 2016:67) menyatakan bahwa ketika siswa memiliki gaya kognitif yang berbeda maka cara memecahkan atau menyelesaikan masalah juga berbeda, sehingga perbedaan tersebut juga akan memicu perbedaan berpikir kritis siswa. Gaya kognitif yang dipilih dalam penelitian ini yaitu, Field Dependence (FD) dan Field Independence (FI) yang berdasarkan pada psikologi (Rahman, 2008). 
Siswa dengan gaya kognitif FD menurut (Desmita, 2014:148) cenderung menerima suatu pola sebagai suatu keseluruhan, mengalami kesulitan ketika fokus pada satu aspek maupun situasi, atau kesulitan dalam memproses informasi yang diterimanya, namun mudah mempersepsi apabila informasi yang telah diterimanya dimanipulasi sesuai dengan konteksnya, dapat memisahkan stimulasi dengan konteksnya, tetapi jika konteksnya berubah maka persepsinya akan lemah. Siswa yang memiliki gaya kognitif FI dapat menerima pola yang menyeluruh secara terpisah, pola yang diterimanya mampu di analisa kedalam komponen-komponennya, informasi yang diterimanya akan diproses menggunakan faktor-faktor internalnya, tidak berurutan dalam mengerjakan tugas, serta merasa efisien jika bekerja secara mandiri.

Permasalahan yang sudah disampaikan peneliti tersebut menjadi tujuan dalam penelitian ini, yaitu untuk mengetahui profil berpikir kritis siswa dalam memecahkan masalah yang ditinjau dari gaya kognitif FD dan FI.

\section{Metode Penelitian Jenis Penelitian}

Jenis penelitian ini adalah penelitian deskriptif kualitatif, dengan tujuan mendeskripsikan profil berpikir kritis 1 siswa yang memiliki gaya kognitif FD dan 1 siswa yang memiliki gaya kognitif FI dalam pemecahan masalah pada soal cerita matematika.

\section{Waktu dan Tempat Penelitian}

Penelitian ini dilaksanakan di SMP

Kristen 2 Salatiga, yang terletak di jalan Jenderal Sudirman 101 B Salatiga. Pengambilan data dilakukan pada bulan Agustus-Maret tahun Ajaran 2018/2019.

\section{Subjek Penelitian}

Subjek yang dipilih dalam penelitian ini memiliki ketentuan sudah pernah belajar materi SPLDV secara formal, selanjutnya memberikan tes GEFT kepada kelas IX A, IX B dan IX D. Pemilihan subjek menggunakan teknik purposive sampling, dalam penelitian didasarkan pada kriteria FD dan FI, dimana FD memiliki skor 0 sampai dengan 9 sedangkan FI memiliki skor 10 sampai dengan 18, serta berdasarkan hasil pertimbangan dengan guru di sekolah tersebut. Subjek dipilih sebanyak dua siswa, 1 siswa dengan gaya kognitif FD dan 1 siswa dengan gaya kognitif FI.

\section{Prosedur}

Langkah-langkah yang digunakan peneliti dalam pengumpulan data sebagai berikut:

1. Melakukan tes GEFT di kelas IX A, IX B dan IX D.

2. Mengoreksi tes GEFT dari ketiga kelas tersebut, kemudian menyusn hasil tes GEFT dengan mengelompokkan gaya kognitif yang dimiliki siswa, sesuai dengan kelasnya masing-masing.

3. Memilih masing-maisng 1 siswa dengan gaya kognitif FD dan 1 siswa dengan gaya kognitif FI. Pemilihan subjek didasarkan pada kriteria FD dan FI, serta berdasarkan hasil pertimbangan dengan guru di sekolah tersebut.

4. Memberikan tes kemampuan berpikir kritis dan pemecahan masalah.

5. Melakukan wawancara untuk mendapatkan informasi lebih.

6. Melakukan analisis dengan tabel berpikir kritis FRISCO yang digabungkan dengan tahap pemecahan masalah Polya.

7. Apabila data belum valid maka dilakukan wawancara kembali dengan subjek.

8. Jika tes pemecahan masalah dengan hasil wawancara sudah valid, maka dilakukan penarikan kesimpulan.

\section{Instrumen Penelitian}

Berikut penjelasan mengenai instrumen yang digunakan dalam penelitian ini:

1. Instrumen Utama

Instrumen utama dalam penelitian ini adalah peneliti itu sendiri, dengan alasan karena peneliti melakukan pengambilan data selama proses penelitian berlangsung, melakukan analisis, kemudian melaporkan hasil penelitiannya.

2. Instrumen Bantu

Penelitian ini bukan hanya menggunakan instrumen utama, tetapi juga 
menggunakan instrumen bantu, berikut penjabarannya:

a) Tes GEFT

Tes yang digunakan peneliti untuk melihat gaya kognitif FD dan FI pada siswa yaitu tes GEFT (Group Embedded Figures Test) dikembangkan oleh Witkin yang diadopsi dari (Kristanti, 2016:28), terdiri dari delapan belas soal, dengan nilai kebenaran satu poin pada setiap nomornya. Gaya kognitif FD memiliki nilai 0 sampai 9 , sedangkan gaya kognitif FI memiliki nilai 10 sampai 18. Tujuan menggunakan tes ini agar peneliti mendapatkan 1 siswa dengan gaya kognitif FD dan 1 siswa dengan gaya kognitif FI.

b) Tes tertulis kemampuan berpikir kritis dan pemecahan masalah matematika

Tes ini menggunakan materi SPLDV kelas VIII yang dikemas ke dalam bentuk uraian sebanyak tiga soal. Instrumen tes yang digunakan peneliti tersebut sudah dilakukan validasi terlebih dahulu dengan 1 dosen pendidikan matematika dan 2 guru mata pelajaran matematika di sekolah tersebut.

c) Pedoman Wawancara
Penelitian ini bukan hanya menggunakan tes tertulis saja, tetapi juga menggunakan pedoman wawancara, agar peneliti mengetahui lebih dalam profil berpikir kritis dalam memecahkan masalah yang dimiliki subjek FD dan FI. Pedoman wawancara yang digunakan dalam penelitian ini berisikan pertanyaan-pertanyaan yang akan ditanyakan kepada subjek, dengan tujuan agar peneliti mengetahui lebih dalam jawaban subjek dalam mengerjakan pemecahan masalah matematika, serta untuk mengetahui profil berpikir kritis yang dimiliki subjek.

\begin{abstract}
Analisis Data
Hasil pemecahan masalah dan berpikir kritis, serta hasil wawancara digunakan peneliti sebagai teknik analisis data. Tahap yang dilalui peneliti yaitu mereduksi data, menyajikan data dan penarikan kesimpulan. Peneliti dalam menganalisis data menggunakan tabel kriteria berpikir kritis FRISCO pada setiap tahap pemecahan masalah Polya, yang diadopsi dari (Rohmatin \& Rahmawati, 2014:28). Berikut indikator yang digunakan dalam penelitian ini:
\end{abstract}

Tabel 1. Kriteria FRISCO pada setiap langkah Pemecahan Masalah Polya

\begin{tabular}{|c|c|c|c|c|}
\hline & $\begin{array}{l}\text { Memahami } \\
\text { Masalah }\end{array}$ & $\begin{array}{l}\text { Membuat } \\
\text { Rencana }\end{array}$ & $\begin{array}{c}\text { Melaksanakan } \\
\text { Rencana }\end{array}$ & $\begin{array}{l}\text { Mengecek/memeriksa } \\
\text { kembali }\end{array}$ \\
\hline $\begin{array}{c}\mathrm{F} \\
(\text { Focus })\end{array}$ & $\begin{array}{l}\text { Membangun } \\
\text { makna tentang } \\
\text { masalah apa yang } \\
\text { akan dipecahkan, } \\
\text { dapat dilakukan } \\
\text { dengan } \\
\text { merumuskan } \\
\text { kembali masalah } \\
\text { dengan kalimat, } \\
\text { gambar, grafik, } \\
\text { atau lainnya. }\end{array}$ & $\begin{array}{l}\text { Memutuskan } \\
\text { strategi apa } \\
\text { yang akan } \\
\text { dipakai untuk } \\
\text { memecahkan } \\
\text { masalah. }\end{array}$ & $\begin{array}{l}\text { Langkah- } \\
\text { langkah } \\
\text { penerapan } \\
\text { strategi yang } \\
\text { terpilih. }\end{array}$ & $\begin{array}{l}\text { Keputusan untuk } \\
\text { memeriksa jawaban yang } \\
\text { telah diperoleh. }\end{array}$ \\
\hline $\begin{array}{c}\mathrm{R} \\
\text { (Reason) }\end{array}$ & \begin{tabular}{l}
\multicolumn{2}{l}{ Memberikan } \\
alasan terhadap \\
hasil rumusan \\
masalah yang \\
telah dibangun.
\end{tabular} & $\begin{array}{l}\text { Memberikan } \\
\text { alsan mengapa } \\
\text { menggunakan } \\
\text { strategi tertentu. }\end{array}$ & $\begin{array}{l}\text { Mengetahui } \\
\text { alasan langkah } \\
\text { penerapannya. }\end{array}$ & $\begin{array}{l}\text { Memberikan alasan } \\
\text { mengapa memeriksa } \\
\text { jawaban tersebut. }\end{array}$ \\
\hline I & Proses penarikan & proses penarikan & Proses & penarikan \\
\hline
\end{tabular}




\begin{tabular}{|c|c|c|c|c|}
\hline (Inference) & $\begin{array}{l}\text { kesimpulan yang } \\
\text { masuk akal } \\
\text { menurut peneliti } \\
\text { (tidak } \\
\text { bertentangan } \\
\text { dengan data yang } \\
\text { ada) dari } \\
\text { rangkaian alasan } \\
\text { yang } \\
\text { dikemukakan } \\
\text { sampai pada } \\
\text { penarikan } \\
\text { kesimpulan. }\end{array}$ & $\begin{array}{l}\text { kesimpulan } \\
\text { yang masuk akal } \\
\text { (menurut } \\
\text { penelitian) dari } \\
\text { rangkaian alasan } \\
\text { menggunakan } \\
\text { strategi tertentu } \\
\text { sampai pada } \\
\text { keputusan untuk } \\
\text { menggunakan } \\
\text { strategi tersebut. }\end{array}$ & $\begin{array}{l}\text { penarikan } \\
\text { kesimpulan } \\
\text { yang masuk akal } \\
\text { (menurut } \\
\text { penelitian) dari } \\
\text { rangkaian alasan } \\
\text { sampai } \\
\text { keputusan } \\
\text { langkah-langkah } \\
\text { penerapannya. }\end{array}$ & \begin{tabular}{lr}
\multicolumn{3}{l}{ kesimpulan yang masuk } \\
akal (menurut penelitian) \\
dari alasan & sampai \\
keputusan & untuk \\
memeriksa & kembali \\
jawaban yang & telah \\
dihasilkan. &
\end{tabular} \\
\hline $\begin{array}{c}\text { S } \\
\text { (Situation) }\end{array}$ & $\begin{array}{l}\text { Mengetahui apa } \\
\text { yang diketahui } \\
\text { dan apa yang } \\
\text { ditanyakan dalam } \\
\text { soal. }\end{array}$ & $\begin{array}{l}\text { Mengetahui hal- } \\
\text { hal penting yang } \\
\text { perlu } \\
\text { diperhatikan } \\
\text { dalam membuat } \\
\text { rencana, } \\
\text { misalnya } \\
\text { mengetahui apa } \\
\text { yang harus } \\
\text { dilakukan ketika } \\
\text { diterapkan } \\
\text { strategi tersebut } \\
\text { pada masalah } \\
\text { yang dihadapi. }\end{array}$ & $\begin{array}{l}\text { Mengetahui hal- } \\
\text { hal penting yang } \\
\text { perlu } \\
\text { diperhatikan } \\
\text { dalam langkah- } \\
\text { langkah } \\
\text { penerapan } \\
\text { strategi, } \\
\text { misalnya urutan } \\
\text { langkah } \\
\text { penyelesaian. }\end{array}$ & $\begin{array}{lr}\text { Mengetahui } & \text { hal-hal } \\
\text { penting yang perlu } \\
\text { diperhatikan dalam } \\
\text { memeriksa jawaban yang } \\
\text { diperoleh. }\end{array}$ \\
\hline $\begin{array}{c}\mathrm{C} \\
\text { (Clarity) }\end{array}$ & $\begin{array}{l}\text { Menjelaskan } \\
\text { istilah-istilah } \\
\text { yang digunkan } \\
\text { (dipantau melalui } \\
\text { wawancara). }\end{array}$ & $\begin{array}{l}\text { Menjelaskan } \\
\text { istilah-istilah } \\
\text { yang digunakan } \\
\text { (dipantau } \\
\text { melalui } \\
\text { wawancara). }\end{array}$ & $\begin{array}{l}\text { Menjelaskan } \\
\text { istilah-istilah } \\
\text { yang digunakan } \\
\text { (dipantau } \\
\text { melalui } \\
\text { wawancara). }\end{array}$ & $\begin{array}{lr}\text { Menjelaskan } & \text { istilah- } \\
\text { istilah yang } & \text { digunakan } \\
\text { (dipantau } & \text { melalui } \\
\text { wawancara). } & \end{array}$ \\
\hline $\begin{array}{c}\mathrm{O} \\
\text { (Overview) }\end{array}$ & $\begin{array}{l}\text { Mengecek semua } \\
\text { hal yang telah } \\
\text { dilakukan dari } \\
\text { alasan, rangkaian } \\
\text { alasan sampai } \\
\text { pada kesimpulan, } \\
\text { apakah semuanya } \\
\text { masuk akal. }\end{array}$ & $\begin{array}{l}\text { Mengecek } \\
\text { semua hal yang } \\
\text { telah dilakukan, } \\
\text { dari alasan } \\
\text { sampai pada } \\
\text { keputusan } \\
\text { tentang strategi } \\
\text { yang akan } \\
\text { dipakai apakah } \\
\text { masuk akal } \\
\text { untuk } \\
\text { memecahkan } \\
\text { masalah yang } \\
\text { dihadapi. }\end{array}$ & $\begin{array}{l}\text { Mengecek } \\
\text { semua hal yang } \\
\text { telah dilakukan } \\
\text { dari alasan, } \\
\text { rangkaian alasan } \\
\text { sampai pada } \\
\text { keputusan } \\
\text { tentang langkah- } \\
\text { langkah } \\
\text { penerapan } \\
\text { strategi yang } \\
\text { telah dilakukan, } \\
\text { apakah masuk } \\
\text { akal untuk } \\
\text { memecahkan } \\
\text { masalah yang } \\
\text { dihadapi. }\end{array}$ & $\begin{array}{l}\text { Mengecek semua hal } \\
\text { yang telah dilakukan, } \\
\text { dari alasan, rangkaian } \\
\text { alasan sampai pada } \\
\text { kesimpulan jantuk } \\
\text { memeriksa jawaban, } \\
\text { apakah semuanya masuk } \\
\text { akal untuk masalah yang } \\
\text { sedang dipecahkan. }\end{array}$ \\
\hline
\end{tabular}




\section{Hasil Penelitian dan Pembahasan}

Tes GEFT yang sudah diberikan peneliti kepada kelas IX A, IX B dan IX D diperoleh hasil yang disajikan pada tabel dibawan ini:

Tabel 2. Hasil Tes GEFT

\begin{tabular}{|c|c|c|c|c|}
\hline \multirow{2}{*}{ Kriteria } & \multirow{2}{*}{$\begin{array}{c}\text { Skor } \\
\text { kebenaran }\end{array}$} & \multicolumn{3}{|c|}{ Banyaknya siswa } \\
\hline & & IX A & IX B & IX D \\
\hline \multirow{10}{*}{ FD } & 0 & 1 & - & - \\
\hline & 1 & - & - & - \\
\hline & 2 & - & - & - \\
\hline & 3 & - & - & - \\
\hline & 4 & - & - & - \\
\hline & 5 & - & - & - \\
\hline & 6 & - & - & - \\
\hline & 7 & - & - & - \\
\hline & 8 & 1 & - & - \\
\hline & 9 & 1 & - & - \\
\hline \multirow{9}{*}{ FI } & 10 & 2 & - & 1 \\
\hline & 11 & 3 & 1 & 2 \\
\hline & 12 & 1 & 1 & 2 \\
\hline & 13 & 2 & 1 & 3 \\
\hline & 14 & 2 & 2 & 6 \\
\hline & 15 & 5 & 4 & 5 \\
\hline & 16 & 3 & 6 & - \\
\hline & 17 & - & 6 & - \\
\hline & 18 & - & 1 & - \\
\hline \multicolumn{2}{|c|}{ Total } & 21 & 22 & 19 \\
\hline
\end{tabular}

Subjek yang sudah terpilih, selanjutnya di konsultasikan kepada guru mata pelajaran matematika di sekolag tersebut. Subjek yang terpilih yaitu 1 subjek dengan gaya kognitif FD dengan skor kebenaran 8 , serta 1 subjek dengan gaya kognitif FI dengan skor kebenaran 17. Subjek dengan gaya kognitif FD disimbolkan sebagai SFD dan subjek dengan gaya kognitif FI disimbolkan sebagai SFI.

Subjek yang sudah terpilih kemudian diberi tes profil berpikir kritis dan kemampuan pemecahan masalah, serta dilakukan wawancara dengan peneliti. Berdasarkan hasil penelitian yang sudah dilaksanakan, maka diperoleh hasil pembahasan profil berpikir kritis dalam pemecahan masalah yang ditinjau dari gaya kognitif FD dan FI, berikut pembahasannya:

1. Subjek dengan gaya kognitif FD (SFD)

Tabel 3. Tabel Kesimpulan SFD

\begin{tabular}{|c|c|c|c|c|c|c|c|c|c|c|c|c|}
\hline \multirow{4}{*}{$\begin{array}{l}\text { Krite } \\
\text { ria } \\
\text { Berpi } \\
\text { kir } \\
\text { Kritis }\end{array}$} & \multicolumn{12}{|c|}{ Tahapan Polya } \\
\hline & \multicolumn{3}{|c|}{1} & \multicolumn{3}{|c|}{2} & \multicolumn{3}{|c|}{3} & \multicolumn{3}{|c|}{4} \\
\hline & \multicolumn{3}{|c|}{$\begin{array}{l}\text { Butir } \\
\text { Soal }\end{array}$} & \multicolumn{3}{|c|}{$\begin{array}{l}\text { Butir } \\
\text { Soal }\end{array}$} & \multicolumn{3}{|c|}{$\begin{array}{l}\text { Butir } \\
\text { Soal }\end{array}$} & \multicolumn{3}{|c|}{$\begin{array}{l}\text { Butir } \\
\text { Soal }\end{array}$} \\
\hline & 1 & 2 & 3 & 1 & 2 & 3 & 1 & 2 & 3 & 1 & 2 & 3 \\
\hline $\mathrm{F}$ & $\sqrt{ }$ & $\sqrt{ }$ & $\sqrt{ }$ & $\sqrt{ }$ & $\sqrt{ }$ & $\sqrt{ }$ & $\sqrt{ }$ & $\sqrt{ }$ & $\sqrt{ }$ & $\sqrt{1}$ & $\sqrt{ }$ & $\sqrt{ }$ \\
\hline $\mathrm{R}$ & - & $\sqrt{ }$ & $\sqrt{ }$ & $\sqrt{ }$ & - & $\sqrt{ }$ & $\sqrt{ }$ & $\sqrt{ }$ & $\sqrt{ }$ & $\sqrt{ }$ & - & $\sqrt{ }$ \\
\hline I & - & - & $\sqrt{ }$ & - & - & - & - & - & - & $\sqrt{ }$ & - & - \\
\hline $\mathrm{S}$ & $\sqrt{ }$ & - & - & - & - & - & - & - & $\sqrt{ }$ & $\sqrt{ }$ & - & - \\
\hline $\mathrm{C}$ & - & - & - & - & - & - & $\sqrt{ }$ & - & $\sqrt{ }$ & - & - & - \\
\hline $\mathrm{O}$ & $\sqrt{ }$ & - & - & $\sqrt{ }$ & $\sqrt{1}$ & - & $\sqrt{ }$ & $\sqrt{1}$ & - & - & $\sqrt{ }$ & $\sqrt{ }$ \\
\hline
\end{tabular}

merumuskan kembali masalah yang terdapat di dalam soal, yaitu tiga tahun yang lalu umur Alan adalah dua kali dari umur Bastian, sedangkan dua tahun yang akan datang umur Bastian lebih muda enam tahun dari umur Alan, tetapi belum dapat memberikan alasan dari rumusan masalahnya, sehingga SFD mampu memenuhi kriteria Focus tetapi tidak dapat memenuhi kriteria Reason dalam memahami masalah. SFD tidak mampu memenuhi kriteria Inference dalam memahami masalah, karena tidak dapat memberikan kesimpulan yang masuk akal dari alasan terhadap rumusan masalah yang sudah dibangun sampai pada penarikan kesimpulan. Menjelaskan yang diketahui dari soal tersebut, yaitu tiga tahun yang lalu umur Alan adalah dua kali dari umur Bastian, sedangkan dua tahun yang akan datang umur Bastian lebih muda enam tahun dari umur Alan, mampu juga menjelaskan yang ditanya pada soal tersebut, yaitu umur Alan dan Bastian sekarang, maka dapat di jadikan bukti bahwa SFD memenuhi kriteria Situation. Belum mampu menggunakan istilah dalam memahami masalah, mengakibatkan SFD tidak mampu memenuhi kriteria Clarity, tetapi mampu memenuhi kriteria Overview karena SFD melakukan pengecekan dari alasan rumusan masalah sampai pada penarikan kesimpulan, dengan cara mengingat ulang semua pernyataan yang sudah disampaikannya dan dicocokkan dengan soal nomor satu.

SFD mampu memutuskan untuk menggunakan cara penjumlahan dan pengurangan dalam menyelesaikan masalah yang dibuanya, dengan alasan menurutnya cara 
itu mudah diterapkan, sehingga SFD dapat memenuhi kriteria Focus dan Reason dalam membuat rencana. Kesimpulan yang dibuatnya dari rangkaian alasan menggunakan cara penjumlahan dan pengurangan, sampai pada keputusan menggunakan strategi tersebut belum masuk akal, tidak dapat mengetahui halhal yang perlu diperhatikan dalam membuat rencana, tidak mampu menggunakan istilah dalam membuat rencana, sehingga tidak mampu menjelaskan istilah yang digunakan, maka SFD tidak mampu memenuhi kriteria Inference, Situation dan Clarity, tetapi SFD mampu memenuhi kriteris Overview karena mampu melakukan pengecekan dari alasan menggunakan cara penjumlahan dan pengurangan, sampai pada keputusan menggunakan cara tersebut.

Rencana yang sudah dibuatnya mampu dilaksanakan meskipun langkah dan jawaban SFD salah. Cara SFD dalam mencari umur Alan yaitu dengan cara menambahkan semua angka yang tercantum di dalam soal, yaitu tiga ditambah dua ditambah dua ditambah enam sehingga umur Alan adalah tiga belas tahun. Umur Bastian diperoleh dari enam dikurangi dua, yang diperoleh dari kalimat dua tahun yang akan datang umur Bastian lebih muda enam tahun dari umur Alan, meskipun jawaban SFD salah tetapi mampu memenuhi kriteria Focus dan Reason, karena selain mampu melaksanakan rencana tetapi juga mampu memberikan alasan dalam langkah penerapannya. Kesimpulan yang disampaikannya tidak masuk akal, tidak mampu mengetahui hal-hal yang perlu diperhatikan dalam melaksanakan rencana, tetapi mampu menjelaskan istilah yang digunakan dalam melaksanakan rencana mengakibatkan SFD tidak mampu memenuhi kriteria Inferencei dan Situation, tetapi mampu memenuhi kriteria Clarity. Mampu memenuhi kriteria Overview karena melakukan pengecekan kembali dari alasan langkah penerapannya sampai pada keputusan langkah penerapannya.

Mampu memutuskan untuk mengecek jawaban dan memberikan alasan perlunya mengecek jawaban, sehingga mampu memenuhi kriteria Focus dan Reason. Memenuhi krteria Inference karena kesimpulan yang disampaikan dari alasan mengecek jawaban sampai keputusan untuk mengecek jawaban sudah masuk akal. Mengetahui hal-hal yang perlu diperhatikan dalam mengecek jawaban, yaitu dengan mencocokkan hasil penyelesaiannya dengan masalah yang terdapat di dalam soal, sehingga memenuhi kriteria Situation. Tidak mampu menjelaskan istilah yang digunakan ketika mengecek jawaban, serta tidak dapat melakukan pengecekan dari alasan mengecek jawaban sampai kesimpulan untuk memeriksa jawaban, sehingga SFD tidak mampu menjawab kriteria Clarity dan Overview.

Pada soal nomor dua, SFI mampu merumuskan kembali masalah yang terdapat di dalam soal, serta mampu memberikan alasan dari rumusan masalahnya tersebut, meskipun masalah yang disampaikannya tidak sesuai dengan masalah yang terdapat di dalam soal tersebut, sehingga SFD dapat memenuhi kriteria Focus dan Reason, SFD menganggap banyak bola pada kotak pertama ada 23 dan banyak bola pada kotak kedua ada 93 , dengan alasan bahwa rumusan masalah tersebut sudah sesuai dengan soal. Kesimpulan dari alasan rumusan masalah sampai pada penarikan kesimpulan tidak masuk akal, sehingga tidak mampu menjawab kriteria Inference. Tidak dapat menjelaskan yang diketahui dari soal, karena langsung menganggap banyak bola pada kotak pertama ada 23 dan banyak bola pada kotak kedua ada 93, meskipun mengetahui yang ditanyakan dari soal yaitu banyak bola pada masing-masing kotak, tetapi SFD tidak dapat memenuhi kriteria Situation. Belum mampu membuat istilah dalam memahami masalah, mengakibatkan SFD tidak memenuhi kriteria Clarity. Kriteria Overview tidak dapat di penuhi juga, karena tidak melakukan pengecekan dari alasan rumusan masalah sampai pada kesimpulan.

Memutuskan strategi yang digunakan dalam menyelesaikan masalah yang dihadapi yaitu dengan cara pembagian, tetapi tidak mampu memberikan alasan yang logis karena menganggap semua orang pasti akan menggunakan cara tersebut dalam mengerjakan, sehingga mampu memenuhi kriteria Focus tetapi tidak memenuhi Reason. Kesimpulan yang dibuatnya tidak masuk akal, 
tidak dapat mengetahui hal-hal yang perlu diperhatikan dalam membuat rencana, tidak dapat menjelaskan istilah yang digunakan karena dalam memahami masalah tidak menggunakan istilah, tetapi mampu melakukan pengecekan dari alasan menggunakan cara pembagian sampai keputusan menggunakan cara tersebut. SFD tidak mampu memenuhi kriteria Inference sampai pada Clarity, tetapi dapat memenuhi kriteria Overview dalam membuat rencana.

Rencana yang dibuatnya pada soal nomor dua mampu diterapkan meskipun langkah dan jawabannya salah, serta mampu memberikan alasan langkah penerapannya. Langkah penerapan yang dibuat SFD yaitu 23 dibagi dua sehingga mendapatkan sebelas koma lima yang dianggap sebagai banyak bola pada kotak pertama, 93 dibagi dua menghasilkan empat puluh dua koma lima yang dianggap sebagai banyak bola pada kotak kedua. Alasan SFD membagi dua pada setiap angka tersebut karena soal tersbebut terdapat dua kotak, sehingga mampu memenuhi kriteria Focus dan Reason dalam melaksanakan rencana. Kesimpulan yang dibuat dari alasan sampai keputusan langkah penerapannya tidak masuk akal, tidak mmapu mengetahui hal-hal yang perlu diperhatikan dalam melaksanakan rencana, serta tidak menggunakan istilah dalam melaksanakan rencana sehingga SFD tidak dapat memenuhi kriteria Inference, Situation dan Clarity. SFD mampu melakukan pengecekan dari alasan sampai pada keputusan mengenai langkah-langkah penerapannya, jadi SFD dapat memenuhi kriteria Overview.

Mampu memutuskan untuk mengecek jawaban, tetapi tidak mampu memberikan alasan mengapa perlu mengecek jawaban yang dibuatnya, keputusan dan alasan yang telah disampaikannya menjadi bukti bahwa SFD mampu memenuhi kriteria Focus, tetapi tidak mampu memenuhi kriteria Reason. Belum mampu memenuhi kriteria Inference karena tidak dapat membuat kesimpulan yang masuk akal dari alasan mengecek jawaban sampai pada keputusan untuk mengecek jawaban. Mengetahui hal-hal yang perlu diperhatikan dalam mengecek jawaban sehingga memenuhi kriteria Situation. Masalah yang dipahami SFD tidak mampu diubahnya ke dalam istilah- istilah sehingga tidak mampu menjelaskan istilah-istilah yang digunakan, tetapi SFD melakukan pengecekan dari alasan mengecek jawaban sampai kesimpulan untuk memeriksa kembali jawaban. Mengakibtkan SFD tidak dapat menjawab kriteria Clarity tetapi dapat menjawab kriteria Overvew dalam menegecek/ memeriksa kembali.

Rumusan masalah yang disampaikan pada nomor 3 yaitu harus mengetahui apakah uang Beni dan Riska cukup untuk membeli roti ulang tahun, dengan alasan karena harga roti tersebut dua ratus tiga puluh lima ribu, jika setengah dari uang Beni adalah sepuluh ribu lebihnya uang Riska, sedangkan tiga kali uang Riska adalah seratus dua puluh ribu lebihnya uang Beni, sehingga SFD memenuhi kriteria Focus dan Reason dalam membuat rencana. Kesimpulan yang dibuatnya dari alasan rumusan masalah sampai pada penarikan kesimpulan sudah masuk akal, sehingga memenuhi kriteria Inference. Tidak dapat mengetahui apa yang diketahui dari soal yaitu menganggap uang Beni adalah sepuluh ribu, sedangkan uang Riska adalah seratus dua puluh ribu, meskipun mengetahui apa yang ditanyakan di dalam soal yaitu apakah uang keduanya cukup untuk membeli roti ulang tahun tersebut, serta berikan alasanmu, namun tetap saja tidak mampu memenuhi kriteria Situation. Masalah yang ditemukan di dalam soal tidak dibuat ke dalam istilah sehingga SFD tidak mampu menjelaskan istilah-istilah yang digunakan, dalam arti tidak memenuhi kriteria Clarity, serta tidak mampu melakukan pengecekan dari alasan rumusan masalah sampai penarikan kesimpulan, jadi SFD tidak dapat menjawab kriteria Overview.

Mampu memutuskan strategi yang digunakan dalam penyelesaian masalahnya, yaitu dengan cara pembagian dan pembandingan, dengan alasan penjumlahan digunakan untuk menjumlahkan uang Beni dan Riska, sedangkan cara pembandingan digunakan untuk membandingkan uang keduanya dengan harga roti, agar mengetahui apakah uang keduanya cukup atau tidak untuk membeli roti ulang tahun, pernyataan tersebut menjadi bukti bahwa SFD mampu memenuhi kriteria Focus dan Reason dalam membuat rencana. Tidak dapat memenuhi kriteria 
Inference, Situation dan Clarity, karena kesimpulan yang dibuat dari alasan menggunakan cara penjumlahan dan pembagian sampai keputusan menggunakan cara tersebut tidak masuk akal, dalam membuat rencana tidak dibuat kedalam model matematika sehingga tidak dapat menjelaskan istilah yang digunakan. SFD jika tidak dapat memenuhi kriteria Overview karena melakukan pengecekan dari alasan menggunakan cara penjumlahan dan pembandingan sampai keputusan menggunakan cara tersebut.

Melaksanakan rencana yang sudah diputuskan meskipun langkah dan jawaban SFD salah, serta mampu memberikan alasan. Berikut langkah penerapan yang dibuat, uang Beni adalah Rp 10.000,00 dan uang Riska adalah Rp 120.000,00, kemudian menjumlahkan uang keduanya yaitu $\mathrm{Rp}$ 130.000,00, kuemudian membandingkan jumlah uang kedunya dengan harga roti ulang tahun, karena harga roti ulang tahun tersebut dua ratus tiga puluh lima ribu rupiah, sedangkan uang keduanya hanya seratus tiga puluh ribu, maka kesimpulan yang dibuatnya adalah uang keduanya tidak cukup untuk membeli roti ulang tahun karena mereka kekurangan seratus lima ribu rupiah. Penjelasan tersbeut menjadi bukti bahwa SFD mampu memenuhi kriteria Focus dan Reason. Tidak dapat memenuhi kriteria Inference karena kesimpulan yang dibuatnya dari alasan langkah penerapan sampai keputusan langkah penerapan tidak masuk akal. Mampu memenuhi kriteria Situation karena mengerti hal-hal yang perlu di perhatikan dalam melaksanakan rencana penyelesaian, serta mampu membuat dan menjelaskan istilah yang digunakan dalam melaksanakan rencana, mengakibatkan SFD mampu memenuhi kriteria Clarity. Kriteria Overview tidak mampu terpenuhi karena tidak melakukan pengecakan dari alasan langkah penerapan sampai pada keputusan langkah penerapan.

Mampu memutuskan untuk mengecek jawaban dengan alasan karena soal nomor tiga membingungkan, jadi SFD perlu teliti dalam menjawab, sehingga dapat memenuhi kriteria Focus dan Reason dalam mengecek/ memeriksa kembali. Kesimpulan dari alasan sampai keputusan untuk mengecek jawaban tidak masuk akal, dengan arti tidak dapat memenuhi kriteria Inference, tetapi dapat memenuhi kriteria Situation_karena mengerti hal-hal yang perlu diperhatikan dalam mengecek jawaban. Tidak dapat memenuhi kriteria Clarity tetapi mampu memenuhi kriteria Overview, karena dalam mengecek jawaban tidak dapat menjelakan kembali istilah yang digunakan, tetapi mampu melakukan pengecekan dari alasan sampai kesimpulan untuk memeriksa jawaban.

2. Subjek dengan gaya kognitif FI (SFI)

Tabel 4. Tabel Kesimpulan SFI

\begin{tabular}{|c|c|c|c|c|c|c|c|c|c|c|c|c|}
\hline \multirow{5}{*}{$\begin{array}{l}\text { Krite } \\
\text { ria } \\
\text { Berpi } \\
\text { kir } \\
\text { Kritis }\end{array}$} & \multicolumn{12}{|c|}{ Tahapan Polya } \\
\hline & \multicolumn{12}{|c|}{2} \\
\hline & \multirow{2}{*}{\multicolumn{3}{|c|}{$\begin{array}{l}\text { Butir } \\
\text { Soal }\end{array}$}} & \multirow{2}{*}{\multicolumn{3}{|c|}{$\begin{array}{l}\text { Butir } \\
\text { Soal }\end{array}$}} & \multirow{2}{*}{\multicolumn{3}{|c|}{$\begin{array}{l}\text { Butir } \\
\text { Soal }\end{array}$}} & \multirow{2}{*}{\multicolumn{3}{|c|}{$\begin{array}{l}\text { Butir } \\
\text { Soal }\end{array}$}} \\
\hline & & & & & & & & & & & & \\
\hline & 1 & 2 & 3 & 1 & 2 & 3 & 1 & 2 & 3 & 1 & 2 & 3 \\
\hline $\mathrm{F}$ & $\sqrt{ }$ & $\sqrt{ }$ & $\sqrt{ }$ & $\sqrt{ }$ & $\sqrt{ }$ & $\sqrt{ }$ & $\sqrt{ }$ & $\sqrt{ }$ & $\sqrt{ }$ & $\sqrt{ }$ & $\sqrt{ }$ & $\sqrt{ }$ \\
\hline $\mathrm{R}$ & $\sqrt{ }$ & $\sqrt{ }$ & $\sqrt{ }$ & $\sqrt{ }$ & $\sqrt{ }$ & $\sqrt{ }$ & $\sqrt{ }$ & $\sqrt{ }$ & $\sqrt{ }$ & $\sqrt{ }$ & $\sqrt{ }$ & $\sqrt{ }$ \\
\hline I & $\sqrt{ }$ & $\sqrt{ }$ & $\sqrt{ }$ & - & $\sqrt{ }$ & $\sqrt{ }$ & - & $\sqrt{ }$ & $\sqrt{ }$ & $\sqrt{ }$ & $\sqrt{ }$ & $\sqrt{ }$ \\
\hline$S$ & $\sqrt{ }$ & $\sqrt{ }$ & $\sqrt{ }$ & $\sqrt{ }$ & $\sqrt{ }$ & $\sqrt{ }$ & $\sqrt{ }$ & $\sqrt{ }$ & $\sqrt{ }$ & $\sqrt{ }$ & $\sqrt{ }$ & $\sqrt{ }$ \\
\hline $\mathrm{C}$ & $\sqrt{ }$ & $\sqrt{ }$ & $\sqrt{ }$ & $\sqrt{ }$ & $\sqrt{ }$ & $\sqrt{ }$ & $\sqrt{ }$ & $\sqrt{ }$ & $\sqrt{ }$ & $\sqrt{ }$ & $\sqrt{ }$ & $\sqrt{ }$ \\
\hline $\mathrm{O}$ & $\sqrt{ }$ & $\sqrt{ }$ & $\sqrt{ }$ & $\sqrt{ }$ & $\sqrt{ }$ & $\sqrt{ }$ & $\sqrt{ }$ & $\sqrt{ }$ & $\sqrt{ }$ & $\sqrt{ }$ & $\sqrt{ }$ & $\sqrt{ }$ \\
\hline
\end{tabular}

Berikut pembahasan SFI dari Tabel 4 untuk soal nomor 1. Masalah yang terdapat di soal nomor satu mampu dirumuskan kembali, yaitu mereka adalah kakak beradik dengan tiga tahun yang lalu umur Alan adalah dua kali dari umur Bastian, sedangkan dua tahun yang akan datang umur Bastian lebih muda enam tahun dari umur Alan. Alasan dari rumusan masalah tersebut adalah, karena yang diketahui hanya hubungan antara umur Alan dan Bastian, sedangkan yang ditanyakan adalah umur mereka sekarang masing-masing, jadi alasan tersebut menjadi dasar dari rumusan masalah yang dibangunnya, dengan kata lain SFI mampu memenuhi kriteria Focus dan Reason dalam membuat rencana. Masuk akal dalam membuat kesimpulan menjadikan SFI dapat memenuhi kriteria Inference. Mampu memenuhi kriteria Situation karena dapat menjelaskan yang diketahui yaitu tiga tahun yang lalu umur Alan adalah dua kali dari umur Bastian, sedangkan dua tahun yang akan datang umur Bastian lebih muda enam tahun dari umur Alan, sedangkan yang ditanyakan adalah umur mereka sekarang. Mampu 
menjelaskan istilah yang digunakan, yaitu A sebagai umur Alan dan B sebagai umur Bastian, sehingga memenuhi kriteria Clarity. Melakukan pengecekan dari alasan rumusan masalah sampai kesimpulan yang sudah dibuatnya, jadi SFI dapat memenuhi kriteria Overview.

Keputusan yang dibuatnya dalam memilih rencana penyelesaian masalah, yaitu dengan cara eliminasi maka SFI dapat memenuhi kriteria Focus. Mampu memenuhi kriteria Reason juga, karena dapat memberikan alasan mengenai cara yang dipilihnya, yaitu cara tersebut adalah cara yang dianggap mudah oleh SFI dalam menyelesaikan masalahnya. Kesimpulan yang dibuatnya tidak masuk akal, sehingga tidak dapat memenuhi kriteria Inference. Mampu mengetahui hal-hal yang perlu di perhatikan dalam membuat rencana, yaitu mengubah data yang diketahui ke dalam bentuk persamaan $\mathrm{A}=2 \mathrm{~B}$ dan $\mathrm{A}=\mathrm{B}+6$, sehingga memenuhi kriteria Situation. Mampu menjelaskan persamaan yang sudah diuatnya, $\mathrm{A}=2 \mathrm{~B}$ diperoleh dari tiga tahun yang lalu umur Alan adalah dua kali dari umur Bastian, sedangkan persamaan $\mathrm{A}=\mathrm{B}+6$ diperoleh dari dua tahun yang akan datang umur Bastian lebih muda enam tahun dari umur Alan, penjelasan SFI tersebut menjadi bukti bahwa SFI mampu memenuhi kriteria Clarity. Mampu juga memenuhi kriteria Overview karena SFI melakukan pengecekan dari alasan memilih cara eliminasi sampai pada keputusan menggunakan cara tersebut.

Cara penyelesaian yang sudah dipilih mampu diterapkan oleh SFI dengan benar dan tepat, sehingga dapat menyelesaikan masalah pada soal nomor satu. Penyelesaian tersebut juga disertai dengan alasan langkah penerapannya, jadi SFI mampu memenuhi kriteria Focus dan Reason dalam melaksanakan rencana. Langkah penyelesaian SFI adalah, mengubah persamaan $\mathrm{A}=\mathrm{B}+6$ menjadi $\mathrm{A}-\mathrm{B}=6$ dengan cara memindahkan $\mathrm{B}$ dari ruas kanan ke ruas kiri, kemudian mengubah persamaan $\mathrm{A}=2 \mathrm{~B}$ menjadi $\mathrm{A}-2 \mathrm{~B}$ $=0$ dengan cara memindahkan $2 \mathrm{~B}$ dari ruas kanan ke ruas kiri. Setelah mengubah kedua persamaan tersebut, selanjutnya menerapkan cara eliminasi sehingga menghasilkan nilai $\mathrm{B}$ yaitu 6, nilai B tersebut digunakan untuk mencari nilai A dengan cara substitusi sehingga menghasilkan nilai A yaitu 12, selanjutnya SFI menambahkan angka tiga pada setiap nilai A dan B. Tujuan SFI menambahkan angka tiga tersebut karena nilai A dan B adalah umur Alan dan Bastian pada saat tiga tahun yang lalu, sedangkan yang ditanyakan adalah umur mereka sekarang. Kesimpulan yang disampaikan dari alasan sampai keputusan langkah penerapannya tidak masuk akal, maka SFI tidak memenuhi kriteria Inference. Mampu mengetahui hal-hal yang perlu di perhatikan dalam langkah penerapannya, yaitu mengubah kedua persamaan tersebut kemudian di eliminasi dan menghasilkan nilai $\mathrm{B}$, dilanjutkan mencari nilai A dengan cara mensubstitusikan nilai $\mathrm{B}$ dan menambahkan angka tiga pada setiap nilai $\mathrm{A}$ dan B, sehingga SFI memenuhi kriteria Situation. SFI mampu menjelaskan istilahistilah yang digunakan dalam langkah penerapannya, sehingga dapat menjawab kriteria Clarity dalam melaksanakan rencana. SFI juga melakukan pengecekan dari alasan sampai keputusan langkah penerapannya, sehigga dapat memenuhi kriteria Overview dalam melaksanakan rencana.

SFI mampu memutuskan untuk mengecek jawaban serta memberikan alasan perlunya mengecek jawaban, sehingga mampu memenuhi kriteria Focus dan Reason dalam mengecek kembali. Kesimpulan yang dibuatnya dari alasan sampai keputusan untuk memeriksa kembali jawaban sudah masuk akal, sehingga dapat memenuhi kriteria Inference. Mampu mengetahui hal-hal yang perlu diperhatikan dalam mengecek jawaban, yaitu dengan cara memasukkan nilai A dan B yang sudah di dapatnya ke dalam persamaan $\mathrm{A}$ $=\mathrm{B}+6$, jika nilai ruas kanan sama dengan ruas kiri maka SFI menganggap jawabannya sudah benar, sehingga dapat memenuhi kriteria Situation. SFI ketika melakukan pengecekan juga mampu menjelaskan kembali istilahistilah yang digunakan dalam menyelesaikan masalah, sehingga dapat memenuhi kriteria Clarity. Melakukan pengecekan dari alasan sampai kesimpulan untuk memeriksa jawaban, sehingga dapat memenuhi kriteria Overview dalam mengecek kembali. 
Pada soal nomor 2, SFI mampu merumuskan kembali masalah yang terdapat di dalam soal, yaitu ada dua kotak yang berisikan bola-bola, dimana dua kali banyaknya bola pada kotak pertama dikurangi banyak bola pada kotak kedua maka banyak bola tersebut ada 23, sedangkan jika tiga kali banyaknya bola kedua ditambah dengan tiga kali banyaknya bola pada kotak pertama maka banyak bola tersebut ada 93. Alasan rumusan masalahnya adalah, soal tersbeut hanya mencantumkan hubungan antara jumlah bola pada dua kotak, sedangkan yang ditanyakan adalah banyak bola pada masing-masing kotak. Rumusan masalah serta alasannya tersebut dapat dijadikan bukti bahwa SFI memenuhi kriteria Focus dan Reason dalam memahami masalah. Kesimpulan yang disampaikan sudah masuk akal, sehingga memenuhi kriteria Inference. Mengetahui data yang terdapat di dalam soal yaitu dua kali banyak bola pada kotak pertama dikurangi banyak boal pada kotak kedua maka banyak bola tersebut ada 23, sedangkan tiga kali banyak bola pada kotak kedua ditambah dengan tiga kali banyak bola pada kotak pertama ada 93. Mengetahui yang ditanyakan yaitu banyak bola pada masingmasing kotak, sehigga memenuhi kriteria Situation. Mampu menjelaskan istilah yang diketahui, yaitu $\mathrm{x}$ adalah banyak bola pada kotak pertama dan y adalah banyak bola pada kotak kedua, jadi SFI memenuhi kriteria Clarity. SFI juga melakukan pengecekan dari alasan sampai kesimpulan, sehingga memenuhi kriteria Overview.

SFI juga mampu menyusun rencana menggunakan cara yang terdapat di materi SPDLV yaitu eliminasi dan substitusi, serta mampu memberikan alasan mengapa menggunakan cara tersebut, sehingga mampu memenuhi kriteria Focus dan Reason dalam membuat rencana. Mampu membuat kesimpulan dari alasan sampai pada keputusan menggunakan cara tersebut dengan masuk akal sehingga dapat menjawab kriteria Inference. Mengetahui hal-hal yang perlu diperhatikan dalam membuat rencana yaitu, mengubah data yang diketahui ke dalam persamaan $2 \mathrm{x}-\mathrm{y}=$ 23 dan $3 x+3 y=93$, kemudian memberikan penjelasan diperolehnya persamaan $2 \mathrm{x}-\mathrm{y}=$ 23 dari kalimat dua kali banyaknya bola pada kotak pertama dikurangi banyaknya bola pada kotak kedua maka banyak bola tersebut ada 23 , sedangkan persamaan $3 x+3 y=93$ diperoleh dari tiga kali banyak bola pada kotak kedua ditambah dengan tiga kali banyak bola pada kotak pertama maka banyak boal tersbeuut ada 93, maka SFI mampu memenuhi kriteria Situation dan Clarity. Melakukan pengecekan dari alasan sampai keputusan mengenai strategi yang dipakai, sehingga memenuhi kriteria Overview.

Rencana yang sudah dibuat SFI mampu diterapkan dengan tepat dan benar, serta diberikan alasan pada langkah penerapannya. Berikut penjelasan langkah penerapan SFI, persamaan $2 \mathrm{x}-\mathrm{y}=23$ diubah menjadi $6 x-3 y=69$ dengan cara mengalikan persamaan tersebut dengan angka tiga, kemudian mengalikan persamaan $3 x+3 y=93$ dengan angka dua sehingga menghasilkan persamaan $6 x+6 y=186$. Kedua persamaan yang sudah diubah selanjutnya di elimiansi sehingga menghasilkan nilai y sebanyak 13, kemudian nilai y di substitusikan dan menghasilkan nilai $\mathrm{x}$ sebanyak 18 . SFI juga membuat kesimpulan pada jawabannya yaitu banyak bola pada kotak pertama ada 18 bola dan banyak bola pada kotak kedua ada 13 bola, sehingga SFI mampu memenuhi krteria Focus dan Reason dalam melaksanakan rencana. Mampu memenuhi kriteria Inference karena kesimpulan yang dibuatnya dari alasan sampai keputusan langkah penerapannya masuk akal. Mengetahui hal-hal yang perlu di perhatikan dalam langkah penepannya, yaitu mengubah dua persamaan yang sudah dibuatnya kemudian dieliminasi dan dilanjutkan substitusi, sehingga dapat memenuhi kriteria Situation. Mampu menjelaskan istilah-istilah yang dgunakan dalam langkah penerapannya, sehingga dapat menjawab kriteria Clarity. Melakukan pengecekan dari alasan sampai keputusan langkah penerapannya, dengan kata lain SFI mampu memenuhi kriteria Overview.

Mampu memutuskan untuk mengecek jawaban yang dibuatnya, dengan alasan supaya jawabannya tidak salah, sehingga dapat memenuhi kriteria Focus dan Reason dalam mengecek kembali. Mampu membuat kesimpulan yang masuk akal dari alasan sampai keputusan untuk memeriksa jawaban, 
sehingga memenuhi kriteria Inference. Mengetahui hal-hal yang perlu diperhatikan dalam mengecek jawaban, yaitu memasukkan nilai $\mathrm{x}$ dan y yang sudah didapatnya ke dalam persamaan $2 \mathrm{x}-\mathrm{y}=23$, jika nilai ruas kanan sama dengan ruas kiri maka SFI menganggap jawabannya benar, sehingga dapat memenuhi kriteria Situation. SFI juga mampu menjelaskan kembali istilah-istilah yang digunakan dalam langkah penerapannya ketika mengecek jawaban, kemudian melakukan pengecekan dari alasan sampai sampai kesimpulan untuk memeriksa jawaban, sehingga SFI dapat memenuhi kriteria Clarity dan Overview dalam mengecek kembali.

Rumusan masalah yang disampaikan SFI pada soal nomor 3 juga diberikan alasan, sehingga SFI dapat memenuhi kriteria Focus dan Reason dalam memahami masalah pada nomor tiga. Berikut penjelasan rumusan masalah dan alasan yang dibuat SFI, Beni dan Riska ingin membeli roti ulang tahun untuk ibunya, harga roti tersebut dua ratus tiga puluh lima ribu rupiah, tetapi yang diketahui hanya setengah dari uang Beni adalah sepuluh ribu kurangnya dari uang Riska, sedangkan tiga kali uang Riska adalah seratus dua puluh ribu lebihnya uang Beni, untuk mengetahui apakah uang keduanya cukup untuk membeli roti ulang tahun maka SFI perlu mencari uang Beni dan Riska masing-masing. Mampu membuat kesimpulan yang masuk akal dari alasan sampai penarikan kesimpulan, sehingga memenuhi kriteria Inference. Mampu menjelasakan yang diketahui dan yang ditanyakan pada soal nomor tiga, sehingga memenuhi kriteria Situation. SFI menjelaskan yang diketahui dari soal tersebut adalah harga roti ulang tahun adalah dua ratus tiga puluh lima ribu rupiah, kemudian setengah dari uang Beni adalah sepuluh ribu kurangnya dari uang Riska, sedangkan tiga kali uang Riska adalah seratus dua puluh ribu lebihnya uang Beni, yang ditanyakan apakah uang keduanya cukup untuk membeli roti ulang tahun tersebut. Menjelaskan istilah yang digunakan yaitu B adalah uang Beni dan $\mathrm{R}$ adalah uang Riska, sehingga dapat memenuhi kriteria Clarity, serta dapat memenuhi kriteria Overview karena melakukan pengecekan dari alasan sampai kesimpulan.
Keputusan dalam memilih cara yang terdapat di dalam materi SPDLV yaitu eliminasi dan substirusi, serta alasan menggunakan cara tersebut menjadi bukti bahwa SFI mampu memenuhi kriteria Focus dan Reason. Kesimpulan yang dibuat dari alasan sampai pada keputusan untuk menggunakan cara eliminasi dan substitusi sudah masuk akal, sehingga SFI mampu memenuhi kriteria Inference. Mampu mengetahui hal-hal yang perlu diperhatikan dalam membuat rencana, yaitu mengubah data yang diketahui di soal ke dalam persamaan $1 / 2$ $\mathrm{B}=\mathrm{R}-10.000$ yang diperolehnya dari setengah uang Beni adalah sepuluh ribu kurangnya dari uang Riska, sedangkan persamaan $3 \mathrm{R}=\mathrm{B}+120.000$ diperolehnya dari tiga kali uang Riska adalah seratus dua puluh ribu lebihnya uang Beni. Istilah yang digunakan dan penjelasan yang diberikan SFI menunjukkan bahwa SFI mampu memenuhi kriteria Situation dan Clarity. Mampu melakukan pengecekan dari alasan sampai keputusan menggunakan cara elminasi dan substitusi, sehingga dapat menjawab kriteria Overview.

SFI mampu melaksanakan rencana yang sudah dibuatnya, serta mampu memberikan alasan langkah penerapannya, sehingga SFI memenuhi kriteria Focus dan Reason. Berikut penjelasan langkah penerapan SFI, persamaan $1 / 2 \mathrm{~B}=\mathrm{R}-10.000$ di ubah menjadi $\mathrm{R}-1 / 2 \mathrm{~B}=10.000$ dengan cara memindah $\mathrm{R}$ dari ruas kanan ke ruas kiri dan mengalikan persamaan tersebut dengan negatif satu, kemudian persamaan tersebut dikalikan dengan angka tiga menjadi $3 \mathrm{R}-11 / 2 \mathrm{~B}=$ 30.000. Persamaan $3 R=B+120.000$ diubah menjadi $3 \mathrm{R}-\mathrm{B}=120.000$ dengan cara memindahkan $\mathrm{B}$ dari ruas kanan ke ruas kiri. Hasil dari dua persamaan yang sudah diubah tersebut dieliminasi oleh SFI sehingga menghasilkan $\mathrm{B}=\mathrm{Rp} 180.000,00$ kemudian nilai $B$ tersbeut disubstitusikan dan mendapatkan nilai R sebanyak Rp 100.000,00. Selanjutnya menjumlahkan uang Beni dan Riska, karena uang keduanya Rp 280.000,00 maka SFI menganggap bahwa uang mereka cukup untuk membeli roti ulang tahun, karena harga roti tersebut $\mathrm{Rp} 235.000,00$. Mampu membuat kesimpulan yang masuk akal dari 
alasan sampai keputusan langkah penerapannya, sehingga dapat memenuhi krteria Inference. Mampu menjelaskan istilahistilah yang digunakan dalam langkah penerapannya, serta melakukan pengecekan dari alasan sampai pada keputusan langkah penerapannya, jadi SFI mampu memenuhi kriteria Clarity dan Overview dalam melaksanakan rencana.

SFI mampu memutuskan untuk mengecek jawaban dan memberikan alasan perlunya mengecek jawaban, sehingga dapat memenuhi kriteria Focus dan Reason dalam mengecek kembali. Mampu memeriksa kesimpulan yang masuk akal dari alasan sampai pada keputusan untuk memeriksa kembali jawaban, sehingga memenuhi kriteria Inference. SFI juga mampu mengetahui hal-hal yang perlu di perhatikan dalam mengecek jawaban, yaitu memasukkan nilai $\mathrm{B}$ dan $\mathrm{R}$ yang sudah didapatnya ke dalam persamaan $1 / 2$ $\mathrm{B}=\mathrm{R}-10.000$, jika ruas kanan dan ruas kiri memiliki nilai yang sama maka SFI menganggap bahwa jawabannya benar, maka SFI dapat memenuhi kriteria Situation. Mampu menjelaskan kembali istilah-istilah yang digunakan dalam langkah penerapannya ketika mengecek jawaban, melakukan pengecekan dari alasan sampai kesimpulan untuk memeriksa jawaban, dengan kata lain SFI dapat memenuhi kriteria Clarity dan Overview.

\section{Simpulan dan Saran}

Kesimpulan dalam penelitian diperoleh siswa dengan gaya kognitif FI atau SFI mampu memahami masalah yang terdapat di dalam soal, mampu membuat rencana penyelesaian, mampu melaksanakan rencana penyelesaiannya, serta mampu melakukan pengecekan kembali pada pemecahan masalah yang dibuatnya. SFI mampu memenuhi semua berpikir kritis baik itu focus, reason, inference, situation, clarity maupun overview untuk soal nomor dua dan tiga. SFI belum mampu memenuhi kriteria berpikir kritis Inference pada nomor satu, karena kesimpulan yang disampaikan SFI pada tahap membuat rencana dan melaksanakan rencana tidak masuk akal dengan masalah yang ada. SFI mampu memproses informasi yang terdapat di dalam soal, mampu merespon masalah dengan baik, serta mampu mengubah soal cerita matematika ke dalam model matematika.

Siswa dengan gaya kognitif FD atau SFD tidak dapat melakukan tahapan pemecahan masalah dengan baik, hanya mampu memenuhi kriteria Focus, Reason dan Overview pada ketoga nomor tersebut. SFD kesulitan dalam memproses informasi yang terdapat di dalam soal, belum mampu mengubah soal cerita matematika ke dalam model matematika, serta memerlukan interaksi yang lebih dengan guru.

Berdasarkan hasil penelitian yang sudah dilakukan oleh peneliti, maka peneliti memiliki beberapa saran, sebagai berikut:

1. Bagi guru, sebaiknya sering memberi latihan pemecahan masalah matematika yang dikemas ke dalam soal cerita kepada siswa, kemudian memperkenalkan tahapan pemecahan masalah Polya kepada siswa, dimana tahapan tersebut dapat membantu siswa dalam memahami masalah, membuat rencana penyelesaian, melaksanakan rencana penyelesaian yang sudah dibuatnya, selanjutnya melatih siswa agar teliti dalam menyelesaikan soal dengan cara mengecek/ memeriksa kembali jawabannya.

2. Bagi siswa, hendaknya sering berlatih memecahkan masalah matematika dalam bentuk soal cerita, termasuk pada materi SPLDV, agar dapat dengan mudah memahami kalimat serta dapat menggunakan informasi yang diterima dari soal.

\section{Daftar Pustaka}

Bahri, Saeful. 2009. Peningkatan Kemampuan Menyelesaikan Soal Cerita Sistem Persamaan Linear Dua Variabel (SPLDV) Melalui Strategi Problem Solving. Jurnal Pendidikan Inovatif, no. 2: pp 78-83.

Cahyono, Budi. 2017. Analisis Keterampilan Berfikir Kritis Dalam Memecahkan Masalah Ditinjau Perbedaan Gender. Jurnal Aksioma, no. 1: pp 50-64.

Desmita. 2014. Psikologi Perkembangan Peserta Didik. Bandung: PT Remaja Rosdakarya. 
Fisher, Alec. 2009. Berpikir Kritis Sebuah Pengantar. Jakarta: Erlangga.

Ifnali. 2014. Penerapan Langkah-langkah Polya Untuk Meningkatkan Kemampuan Pemecahan Masalah Soal Cerita Pecahan Pada Siswa Kelas VII SMP Negeri 1 Palu. Jurnal Elektronik Pendidikan Matematika Tadulako, no.02: pp 147-158.

Kristanto, Beny Rafika (2016). Analisis Proses Berpikir Dalam Menyelesaikan Soal Geometri Ditinjau Dari Gaya Kognitif Field Independent dan Field Dependent Pada Siswa Kelas VIII SMP Negeri 4 Boyolali. Universitas Kristen Satya Wacana Salatiga.

Mahardiningrum, Anita Sri. 2017. Profil Pemecahan Masalah Matematika Siswa SMP Pangudi Luhur Salatiga Ditinjau Dari Berpikir Kritis. Jurnal Mosharafa, no. 1: pp 78-84.

Nisa, Roisatun. 2016. Profil Berpikir Kritis Siswa SMP dalam Menyelesaikan Soal Cerita ditinjau dari Gaya Kognitif dan Kemampuan Matematika. Jurnal Apotema, no.1: pp 66-76.

Peraturan Menteri Pendidikan Nasional No. 22 tahun 2006 tentang standar isi.

Rahman, Abdul. 2008. Analisis Hasil Belajar Matematika Berdasarkan Perbedaan Gaya Kognitif Secara Psikologis dan Konseptual Tempo pada Siswa Kelas X SMA Negeri 3 Makasar. Jurnal Pendidikan dan Kebudayaan, no. 072: pp 452-473.

Rohmatin, Dian Novita. 2012. Profil Berpikir Kritis Siswa SMP dalam Memecahkan Masalah Geometri ditinjau dari Tingkat IQ. Gamatika, no.1: pp 1-9.

Santrock, John W. 2004. Psikologi Pendidikan. Jakarta: Prenadamedia Group.

Sugiyono. 2012. Metode Penelitian Kuantitatif Kualitatif Dan R\&D. Bandung: Alfabeta. 